Vol. 6, n² | 2002

Varia

\title{
Transportation, Penal Ideology and the Experience of Juvenile Offenders in England and Australia in the Early Nineteenth Century
}

Heather Shore

\section{(2) OpenEdition \\ Journals}

Electronic version

URL: https://journals.openedition.org/chs/416

DOI: $10.4000 /$ chs. 416

ISSN: 1663-4837

\section{Publisher}

Librairie Droz

\section{Printed version}

Date of publication: 1 December 2002

Number of pages: 81-102

ISBN: 2-600-00812-8

ISSN: $1422-0857$

\section{Electronic reference}

Heather Shore, "Transportation, Penal Ideology and the Experience of Juvenile Offenders in England and Australia in the Early Nineteenth Century", Crime, Histoire \& Sociétés / Crime, History \& Societies [Online], Vol. 6, n² | 2002, Online since 25 February 2009, connection on 22 March 2022. URL: http:// journals.openedition.org/chs/416 ; DOI: https://doi.org/10.4000/chs.416

This text was automatically generated on 22 March 2022.

(C) Droz 


\title{
Transportation, Penal Ideology and the Experience of Juvenile Offenders in England and Australia in the Early Nineteenth Century ${ }^{1}$
}

\author{
Heather Shore
}

In 1818 the Ordinary of Newgate, the Reverend Horace Salisbury Cotton, gave evidence to a parliamentary Select Committee, regarding prisoners' attitudes to transportation:

'I have often heard them, when sentence of transportation has been passed... return thanks for it, and seem overjoyed by the sentence... the very last party that went off I happened to see them; when they were put into the caravan they shouted and huzzaed, and were very joyous; and several of them called out to the keepers, who were then in the yard, «Aye, the first fine Sunday we have we will have a glorious kangeroo hunt at the Bay»"2.

In the mind of Horace Salisbury Cotton, and others of his generation, such rhetoric provided a rationale and justification for transportation. Not only was it advantageous to society but, according to this perspective, it also benefited the criminal. For the criminal, it was argued, transportation provided opportunity, difference, and removal from the buds of corruption by which he or she were tainted at home. Transportation, increasingly to be repackaged as a variety of colonial emigration, offered the convict the potential to remake themselves. Nowhere was this ideology more pervasive than in the treatment of the youngest group of convicts, juvenile and youth offenders. Thus the idea of rebirth, of re-invention, was often implicit in discussions of the transportation of young people, to the extent that a digested version of the reformatory rhetoric was at times echoed by the children themselves. Thus William Johnson told an interviewer that he:

'Does not regret... going abroad... has a brother at the Bay - has been there about 2 years - heard he was at his trade \& doing well... they were talking all night long about the bay - said he did not care about it - all he had to say against was the shortage of food - the work was nothing to him did not mind it - Anxious to be away - most everyone is glad to be out the country's. 
3

reformatory rhetoric, surviving accounts bear witness to an array of responses. Fear, anticipation and resignation were characteristic of these.

The main research on transported juveniles in the early nineteenth century is to be found in the Antipodean literature. However, despite the variety of colonial experience, the existing work has concentrated largely on the regime at Point Puer, the juvenile station established in Van Diemen's Land in $1834^{4}$. Moreover, despite more recent attempts to recapture the experience of the Point Puer boys, most work concerned with juvenile transportation has focused on the administrative and ideological machinery of the penal regime ${ }^{5}$. Correspondingly, British juvenile justice as a historiographical area has developed rapidly in recent years. Research by Peter King and others, has complemented more established work by Margaret May, Susan Magarey, and Leon Radzinowicz in exploring the 'discovery' of juvenile delinquency as a specific category during the nineteenth century ${ }^{6}$. However, Radzinowicz excepted, this work rarely deals directly with the transportation of juveniles. Peter King's very substantial articles concentrated on developing a set of key explanations for the rise of juvenile delinquency, and the progress of juveniles into the justice system between the 1780s and the 1830s. Susan Magarey developed the idea of the 'invention' of the juvenile delinquent through the criminalisation of petty juvenile activities engendered with the extension of summary jurisdiction, and reinforced by the Metropolitan Police Act of 1829. Margaret May described the ideological and legislative forces which during the 1830s and 40s clarified the conceptual idea of the juvenile offender. The transportation of juvenile offenders has only been mentioned in passing in this work. The project of reform, aimed particularly at young offenders, was being developed both in Britain and on the Continent at this time. Arguably, the development of a juvenile specific institution in Van Diemen's Land, at Point Puer, suggests that the message of reform was being carried to the colonies. Thus, Kim Humphery has shown how the reform ideology was established and developed under the guise of the Commandant, Charles O'Hara Booth, and the influence of recommendations such as those of Benjamin Horne, the British prison inspector 7 . However, in reality the ambitions of Point Puer failed to be realised. Ideology is perhaps most fruitful when it is married with discipline and the discipline of Point Puer was arguably a direct consequence of its role in the economy of Port Arthur. Thus whilst the juvenile offenders who became its inmates may well have become the recipients of reform strategies, in the guise of colonial re-training, like their fellow juveniles in the colony, their experience was also one characterised by conflict and struggle. This article will discuss the development of a reformatory rhetoric both at home and in the colonies, and consider this in relation to the experiences of transported juvenile delinquents who were sent to Point Puer, or assigned to an employer upon their arrival in Van Diemen's Land. In doing so, it will establish the significance of juvenile transportation in the era of penal transformation.

\section{Juvenile Transportation}

5 Transportation was one of the premier secondary punishments between the 1820 s and 1840s. In the more specific context of the treatment of juvenile offenders it was one of a variety of strategies that were resorted to in the shift towards the development of a separate juvenile justice system. This was accomplished in various stages. From the late

Crime, Histoire \& Sociétés / Crime, History \& Societies, Vol. 6, n² | 2002 
1840s, after the demise of transportation to New South Wales and Van Diemen's Land, the energy of the penal debate would re-focus more fully on domestic institutions. After the institutional experiments of the 1830s, which had resulted in the establishment of Parkhurst for juvenile offenders, opinion was to shift increasingly back to the models favoured by the philanthropic sector ${ }^{8}$. Thus more humane modes of treatment that addressed both the 'criminal' juvenile and the 'peripheral', or at risk, youth were to be embraced'. This ethos would be expressed in the passage of the Industrial and Reformatory Schools Acts of the 1850s which established the principle of separate custodial provision for juveniles ${ }^{10}$. This article is concerned with the earlier stage, when penal policy more generally, as well as that dealing specifically with juveniles, was structured around a more punitive model. The deportation of children and youths in this period was very much an extension of this model. During the $1830 \mathrm{~s}$ there was an ongoing critique of the nature of institutional provision for children which extended to both the hulks and the colonial institutions. This in turn was to lead to the more enlightened attitudes of the mid-century. Whilst transportation as a main punishment would cease the deportation of juveniles continued, albeit dressed in the clothes of colonial emigration.

6 The use of transportation in the early nineteenth century was paralleled by the increasing resort to emigration of poor and delinquent children by such organisations as the Philanthropic Society and the Children's Friend Society, to both Australia and South Africa ${ }^{11}$. This practice had its roots in schemes first mooted in the seventeenth century, and by the early nineteenth century was closely bound up with the reformatory rhetoric. Hence, transportation and emigration for the young was increasingly remodelled into forms of colonial retraining. Indeed the great penal experiment of Parkhurst, first opened as a penitentiary for young offenders in 1838, at least in theory, exemplified the conjunction of the ethos of transportation and of colonial emigration and retraining ${ }^{12}$. The transportation of children had been a legislative fact since the act of 1718 , which re-organised the commercially viable transportation of felons to the North American plantations. This act was a response to anxieties about crime in the early eighteenth century, and was intended to make transportation a more effective punishment. The act permitted the penal transportation of children aged between fifteen and eighteen to the North American plantations, with the hypothetical provision that they consented to $\mathrm{go}^{13}$. With the cessation of American transportation after the War of Independence and the reemergence of transportation in its Australian form in the late 1780s, the practice of transportation for the young continued (though this time no lip service was paid to the issue of consent). During this period of transportation large numbers of young people were sent to Australia. According to F. C. Hooper, in his study of Point Puer, from 1803 to 1853 between 10,000 and 13,000 convicts aged eighteen and under arrived in Van Diemen's Land, of whom approximately $90 \%$ were male. During the $1830 \mathrm{~s}$ the proportion of male juvenile convicts arriving in Van Diemen's Land was around $20 \%$ of all convicts. In contrast, around $16 \%$ of convicts arriving in New South Wales were young males and females ${ }^{14}$. Whilst very young children were occasionally sentenced to transportation, it was not usually the practice for them to be sent until they were fourteen. On the whole the courts seem to have been loath to sentence younger children to a four-year stay on the hulks ${ }^{15}$. Children were sentenced to transportation for a variety of offences, however, the vast majority were convicted for larceny ${ }^{16}$. Moreover, those juveniles sentenced to death virtually all had their sentences reduced 
to transportation, for example, Mary Tyler aged 13, who in 1809 was sentenced to death at the Old Bailey, for stealing a cart and gelding ${ }^{17}$. Age was not the only factor to affect the likelihood of being transported. Whilst the bias towards a youthful population of transportees was evident, factors such as the perception of an offender being particularly 'hardened', or having 'criminal connections', may have turned the court towards a sentence of transportation. Equally, crimes associated strongly in the public mind with perceptions of the 'criminal class', for example picking pockets, were likely to result in a sentence of transportation. For example seventeen-year-old Robinson alias Burton from Clerkenwell who had been sentenced to seven years transportation, 'Used to pick pockets in the City - best place more people walking about... his station was on Blackfriars bridge in the morning, and from St. Paul's to Temple Bar in the evening and afternoon'18. Once sentenced, juveniles were committed to Newgate and from there taken to Chatham or Woolwich and the hulks.

7 In the early nineteenth century there were two juvenile specific hulks, the Bellerophon and the Euryalus. The Bellerophon's adult prisoners were removed in 1824 for the ship to be made exclusive to juvenile boys. According to a report of that year, from John Capper, the superintendent of the hulks establishment, the Bellerophon was to be reserved for boy convicts aged no older than fourteen, however within a few months the hulk took older boys as well ${ }^{19}$. At the end of 1825 the boys were transferred to a new prison hulk, the Euryalus, an ex-frigate of the Trafalgar fleet, moored at Chatham. Over the twenty years that these hulks serviced juveniles, about 2,500 boys of fourteen and under passed through them. There were also considerable numbers of older boys both in the juvenile hulks and distributed amongst the other prison hulks. Conditions on the Euryalus were frequently the subject of concern. Certainly by the 1830 s if not before, damning comment can be found in the various parliamentary Select Committees ${ }^{20}$. From the Euryalus boys were transported both to New South Wales and to Van Diemen's Land.

\section{Reformation}

8 The move towards colonial emigration by the mid-nineteenth century was to some extent based on a collective belief that boys were not adverse to transportation, that in fact they looked forward to it, their only qualms being the leave-taking of family and friends. This suited well elite opinion that was concerned with form rather than function. Thus the processes that the boys went through, the hulks, the voyage, and the experience of penality, were the main subjects of discussion rather than the appropriateness of transportation. The hulks, as we have seen, epitomised the great dread of 'contagion' and 'contamination'. In 1835, W. A. Miles received information from the juvenile penal settlement in Van Diemen's Land, Point Puer, indicating that the boys' tenure in the Euryalus had aggravated their criminal tendencies: 'however criminal they might have been before their Commitments, he seriously believes that previous to their Imprisonment in that accursed Hulk... they were comparatively innocent $^{21}$. Transportation, whether it was carried out through penal statute or cloaked in humanity by philanthropy, was for England's rulers a fine concept. It pleased the traditionalists who wanted young thieves out of sight and out of mind, but not on the gallows; it pleased the advocates of both laissez-faire and of intervention. For the former, there was no need to interfere in the affairs of businessmen and employers at 
home, the colonies could be left to sort themselves out; for the interventionists, transportation allowed decision-making and action, control and a paternalist role limited by geographical separation ${ }^{22}$. Yet transportation was more than a policy of removal. Whether through altruism or self-interest, there was a growing feeling that it should provide a new start, a chance to break free from the environment and companions that, it was believed, were a strong inducement to crime. However, enough of the old school still existed, wanting to maintain the punishment element of transportation, needing it to have some deterrent effect.

The mid-1830s, both in Britain and in Van Diemen's Land, represented the clashing of the two penitentiary ideals. Institutional regimes at home were caught in a dichotomy between a more punitive and a more reformative regime. The re-emergence of the penal debates from the end of the French wars had been considerably focussed on the specific problems of young offenders. Indeed, it was in the realm of juvenile justice that some of the most vociferous campaigners for penal reform first appeared. For example, the Prison Discipline Society, active in from the 1820s, had evolved from the Committee behind the Report of the Committee for Investigating the Causes of the Alarming Increase of Juvenile Delinquency in the Metropolis (1816) ${ }^{23}$. William Crawford, one of the two first Inspectors of Prisons, had earned his spurs in his work as a key member of this group of mainly Quaker philanthropists. The Committee also included two of the brother-inlaws of Elizabeth Fry, Thomas Fowell Buxton, partner in the Truman, Hanbury and Buxton brewery, and later Whig politician, who campaigned for the abolition of the death penalty except in cases of murder, and Samuel Hoare, banker, and Chairman of the Society for the Improvement of Prison Discipline ${ }^{24}$. The 1820 s and 30 s can be characterised as a period of tensions in the arena of juvenile justice. On the one hand (hardly new) ideas about the reform of the convict were being reworked by a new generation of philanthropists ${ }^{25}$. On the other hand, inherent in their models of reform was the issue of discipline, and the need for a punitive rationale. Ironically, it seemed, reformation could only be truly effected with a disciplinary regime. This inevitably led to conflict. Underlying this conflict was perhaps another layer of tensions, that of the ideological personnel of the penal regimes. The role of philanthrophy is well-known in the history of juvenile justice in the early nineteenth century ${ }^{26}$. Thus during this period philanthropists had a considerable impact on the direction and development of state responses to the juvenile crime problem. Whilst, by the 1830s, the state monopolised the management of delinquency, it also incorporated many of the methods and approaches which had been utilised by the philanthropic sector. Moreover, as I suggested earlier, many of those individuals working in what we might call the voluntary sector in the 1810s and 20s, were by the late 1820s increasingly absorbed into the body of penal professionals who were influencing government legislative policies. Arguably by the 1830 s and 40 s the private and public sectors were becoming increasingly intertwined ${ }^{27}$. Indeed, looking at the literature in pamphlets, reports, Select Committees from this time, what we find is a very incestuous and very circumscribed world. Moreover, if we look more broadly at the cross-fertilisation of ideas in Europe and America, again we see similar personnel moving around the various congresses, which have been described by Chris Leonards, and through exchange and inter-change of ideas on visits to key penal institutions on the continent and in America ${ }^{28}$. Thus William Crawford, just prior to his appointment as one of the First Inspectors of Prisons, visited the American penitentiaries in $1834^{29}$, and Sydney 
Turner, from 1841 the Chaplain of the Philanthropic Society, visited Mettray, the French agricultural reform school, in the mid-1840s ${ }^{30}$.

By the late 1840s the juvenile justice system in Britain and Europe was quickly establishing itself. From the mid-century regular congresses were held with the result that the role of individuals within the reform discourse became increasingly professionalised $^{31}$. Moreover, arguably by mid-century the philanthropists were in the ascendant, the reformist tendencies had overtaken the disciplinary regime. In Britain, the most influential contributor to the juvenile justice debate from the 1840s was Mary Carpenter, whose vision of reform and welfare was notably differentiated from the existing systems, and those adopted in the previous decades. In 1851 Carpenter vigorously attacked the system at Parkhurst, which for her smacked too much of disciplinary regimes that should have been left behind:

'It attempts to fashion children into machines instead of self-acting beings, to make them obedient prisoners within certain iron limits, not men who have been taught how to use their liberty without abusing it; without this knowledge, and the power of employing it, we have seen that the best instruction, the Word of God itself, but little avails its possessor. Such a system must fail; for the boy whose heart has never been purified and softened by any good home influence, who has always done 'what is right in his own eyes', will never give a willing obedience where his power can have no free exercise, where there is no softening power of love to subdue him, where he can never hear from woman what should have been the entreating tones of a mother, where he regards with profound suspicion the appointed agents of his reformation' 32 .

11 Nevertheless, even prior to Carpenter's admonitions, the reformation of the juvenile offender had been conditional upon the recognition of different groups of offenders.

\section{Delinquent Subjects}

12 Inherent in the reform agenda was the notion that juvenile offenders would prove more receptive subjects. Clearly some youths represented more of a challenge than others, and so great concern was shown in regard to the children's backgrounds in order to ascertain their suitability for reformation. In the mid-1830s a group of boys destined for transportation were interviewed on the Euryalus hulk at Chatham, by William Augustus Miles, a close contemporary of Edwin Chadwick ${ }^{33}$. Much emphasis was placed on their backgrounds and the circumstances which, as they perceived it, brought them to their present situation ${ }^{34}$. Nineteen of the interviewed juveniles were transported to Van Diemen's Land, and eight spent at least some time at Point Puer ${ }^{35}$. Most of the boys were aged sixteen and under, though two seventeen-year-olds, and one boy aged nineteen were also present. Most of them came from London, though there were also two Edinburgh boys and one from Loughborough. Arguably the high number of London boys is a reflection of Miles's particular interest in London crime, rather than any inherent bias in the hulks system towards London boys ${ }^{36}$. The majority of boys were convicted of larceny, and the London boys had been tried at the old Bailey, or the Central Criminal Court as it was now known, with the remainder at the Middlesex Quarter Sessions at Clerkenwell. Some of them had previous convictions, or were known to have, what were referred to as, 'bad associations' ${ }^{37}$. Thus thirteen-yearold Thomas O'Donnell had been 'known to be the associate of bad characters'; fourteenyear-old John Darville was turned out of his home by his hard-drinking step-father; another fourteen-year-old James Edwards had a brother on board the Euryalus; George 
Hickman, aged fourteen, had been previously in custody, and used to thieve with another boy on the Euryalus, a seventeen-year-old called Robinson (otherwise Burton) ${ }^{38}$. The type of crimes that the boys committed was on the face of it, minor. However as I suggested earlier, the boys who were transported tended to be those who were a) seen as 'hardened' re-offenders, and as a corollary to that, connected to 'bad associations' b) were orphans or children in a home situation identified as precarious, thus were seen as suitable material for colonial emigration. Clearly not all the children transported fell into these categories. However, those boys who were transported to Van Diemen's Land gave a potted history of their offending that was subsequently recorded in their conduct registers. The following stories were typical (paraphrased):

Samuel Holmes, aged fourteen, who had been transported for larceny had previously been convicted of felony. He admitted to previous convictions for which he received two months, and one month's imprisonment.

James Edwards, aged fifteen, had been transported for burglary. He had previously been convicted for stealing from a shop, and had received various short sentences of imprisonment for stealing a pudding, plums, picking-pockets, and vagrancy.

George Hickman, aged sixteen, had been transported for larceny from the person. He was tried with another boy, Thomas Whitford aged eighteen. He had been convicted of stealing from the person, and remanded on a felony charge previously; receiving three months imprisonment for stealing a necklace, three months for stealing a handkerchief, and two months for stealing a teapot ${ }^{39}$.

Clearly the reliability of the information that the boys provided should not be too readily accepted. In their favour, given that they had been convicted and sentenced it could be argued that they had little to hide. Nevertheless in the undoubtedly hard environment they found themselves in, there may have been some incentive to exaggerate one's past, to give the impression of experience, masculinity, and maturity in crime ${ }^{40}$. Yet, whilst these children were 'experienced' by the criteria of the penal system, except for very few, their stories recount little more than the petty misdemeanours, thefts, and disorderliness of working-class youth.

Despite the mundanity of the circumstances of these crimes it is clear that contemporary commentators, Miles included, were keen to emphasise the boys' apparent links to the criminal networks of the metropolis, providing a strong justification for the rationale of removal and separation so inherent in the transportation and emigration of juveniles. For instance, if we take the three boys mentioned above, according to information taken from the Euryalus interviews [paraphrased]:

Samuel Holmes had no mother, and his father was a waterman and a drunkard. He told Miles that he lodged at a house in 3 Compass Court in Stepney, where he paid the landlord 2/6 a week, 'provided I brought and sold to him all that I might steal'. James Edwards father had ran away leaving his mother, a drinker, to support four children. One of these was already on the Euryalus under sentence of transportation. The boy spent all his money on gambling, and sold his stolen goods to a woman in Wentworth street, on the borders of Spitalfields. He described to Miles, a housebreaker living in the same road who lodged both juvenile boys and girls, and sent them out to thieve.

George Hickman indicated a lengthy familiarity with the criminal networks of London. He claimed to have been stealing for three years, and was fond of gambling. He sold his 'plunder' to two sisters who lived in Field Lane. His mother was a nurse, and father a working jeweller, 'they are both sober persons' ${ }^{\prime 4}$. 
On the whole these boys were resigned to transportation, easily slipping into the role provided for them in the prevailing ideology. Thus they were caught in a life of crime, they had corruptive friends and criminal connections from which they sought refuge, transportation offered them escape - hence, transportation became in their accounts less a punishment and rather a benevolent system of rescue. So seventeen-year-old Michael Driscoll, described as an experienced pickpocket, considered, 'that his course of crime is terminated for seven years - and has no wish to return to his old haunts'. Fourteen-year-old Philip Maine confessed to Miles, 'He does not much care about his present situation, nor mind being transported' ${ }^{42}$. A boy identified only by the initials G.W., a 'respectable' nineteen-year-old from Hackney who stole to feed his appetite for the 'dissipated society he met at the theatres', echoed elite attitudes to the majority of youths awaiting transportation:

'From his experience of the characters of the boys sentenced to transportation he should consider reformation to be hopeless, owning to the youths having been so badly connected, and so badly trained... thinks that if they return to their haunts and to their parents they would be as criminal as ever... Boys under sentence to leave the country now wish to go abroad, where they will be under less restraint they think... formerly they were desirous to stop and would even lame themselves for that purpose' ${ }^{\prime 4}$.

16 An overwhelming theme of these accounts, besides fear and resignation, is the sense of futility. When asked about reforming, fifteen-year-old William Cook summed up the feelings of many of his fellow juveniles:

'I would not trust a thief - they can never turn right - if they get a place it would be to run away after a month or so with anything they could get hold of - as for myself I would rather go abroad - I have no friends and if I was to get into a place I should be enticed away again'44.

17 To some extent the ideology of separation and reform had been absorbed by them. These were boys who came from poor homes, where unemployment, bereavement and illness were commonplace, who had carved out their own alternative life strategy of petty crime and theft. Transportation was rapidly becoming, in the early nineteenth century, an inevitable risk of such a life-style. To some extent the very distance of Australia and Van Diemen's Land, gave a certain mystique and provided a space where another alternative existence could be played out. Few boys seemed much aware of, or willing to consider, the essential penality of the transportation experiment, though, one boy, thirteen-year-old Thomas O'Donnell admitted to being, 'afraid of going to the Bay and would prefer the House of Correction' ${ }^{\prime 45}$.

\section{Van Diemen's Land}

The penal establishment in Tasmania was based at Port Arthur on the Tasman Peninsula. The tiny penal colony that was established on the tip of the peninsula in 1830 has become one of the most enduring monuments to the convict period. At Port Arthur the relentless and grinding apparatus of reform truly reflected Foucault's, 'carceral system', what Robert Hughes describes as the 'hermetic regularity of its discipline ${ }^{46}$. Thomas Lempriere, who had served as a commissary officer at Port Arthur, and previously at Macquarie Harbour, remarked that:

'a penal settlement is, and ought to be, an abode of misery to those whose crimes have sequestered them from the society of their fellow-creatures. Were it a place of 
comfort, the very object for which such establishments are formed, the punishment and reform of malefactors, would become nugatory' ${ }^{47}$. Whilst the ideology of reformation, imported from the mother country, may well have oiled the wheels of the penal machine, the real function of Point Puer was to reshape juvenile convicts into more useful colonial workers ${ }^{51}$. In this way it corresponded with institutions in Britain. The Farm Schools in particular made explicit the link between re-training and the colonies, and indeed sent out children to South Africa, Western Australia and Canada ${ }^{52}$. Miles described the system of training at Point Puer as one in which, 'Industrious Habits and a strict Observation of Rules are inculcated and enforced'53. The boys were allowed to chose from six trades; carpenters, sawyers, nailers, shoemakers, tailors and agricultural labourers. According to the Commandant, Charles O'Hara Booth, these were skills, 'most useful in a new country'54. Miles described what we can only assume was a typical day at Point Puer:

'The boys rise at half past five; and after attending prayers, which are read by their catechist, they are all marched off in military order to agricultural employments 'till half-past eight when they return to breakfast; at half past nine the boys proceed to their different trades; at one they dine, and continue at work from two 'till five; between five and six they sup; from six to eight a school is opened under the direction of the schoolmaster; from eight to nine is devoted to prayers, after which the boys retire to bed ${ }^{55}$.

Here then was the penitentiary ideal, the days broken down and structured into a system that in theory controlled their working hours. The unyielding and unskilled juvenile delinquents, Britain and Ireland's human flotsam and jetsam, were to be remade into compliant, skilled workers. The man who shaped Port Arthur and Point Puer was Charles O'Hara Booth (formerly of the $21^{\text {st }}$ Fusiliers). He combined a program of reformation, religious and industrial training with a strict disciplinary regime ${ }^{56}$. However, throughout the period of O'Hara's tenure, there were frequent problems of disobedience. The numbers of boys at the small colony of Point Puer were especially problematic, and a crisis point was reached in 1843 when a particularly unpopular overseer, Hugh McGine, was murdered by a pair of fourteen-year-olds, Henry Sparks and George Campbell ${ }^{57}$. The system at discipline at Point Puer was the object of some detailed observations by contemporary social commentators, for example, the Quakers, James Backhouse and George Washington Walker, James Ross (the editor of the Hobart Town Almanack), a journalist David Burn, and a French visitor, Captain Laplace. Much of the commentary left by these people was favourable and sympathetic to the aims of

Crime, Histoire \& Sociétés / Crime, History \& Societies, Vol. 6, n² | 2002 
O'Hara - though mixed with an obvious repugnance for the visual effects of the convict system. For example Laplace commented of a visit to Point Puer that the boys were,

'Generally dirty, and their clothes falling in rags. On these young faces, I could find nothing childlike, but features that were hard, emphatic and coarse; in their expression, the insolence of crime mixed with the careless indifference of youth; nothing which could arouse in me a feeling of pity for these victims of the severity of the British laws...'

On the whole the criticism of the system was aimed much more at the distant mother country than at the overseers of the colony: 'England, although constantly increasing the number of young prisoners, seemed to want to leave the cost entirely to the local treasury ${ }^{158}$.

Central to the discussion about the penal colony were the disciplinary regimes enforced by O'Hara Booth. According to evidence given to the 1837-1838 Select Committee on Transportation, there was a strict system of discipline at the boys colony ${ }^{59}$. Punishment was graded, from the most trivial to the more serious offences. At the most basic was confinement to the muster ground, during work breaks, which would be spent scavenging the ground rather than in amusements. The next grade of punishment involved the prisoner being kept to their cell (a space measuring $5 \mathrm{ft} 6$ inches by $3 \mathrm{ft} 6$ inches) outside work and school hours, eating their meals in silence, 'until they manifest a disposition to amendment'. If amendment was not achieved, meals were replaced by bread and water. If all this failed, punishment on the breech was resorted to, though O'Hara Booth, noted, 'This measure is never resorted to until every other means to reform have been tried without effect, unless under some particular circumstances, such as a mutinous disposition' ${ }^{60}$. What grades of 'mutinous disposition' provoked a beating was not commented upon. How far the disciplinary regime at Point Puer differed from those employed in comparable juvenile institutions remains to be seen. In Britain, at least within the voluntary sector at this time, the tide was turning against corporal punishment, for example Charles Forss of the Children's Friend Society claimed that the Society never whipped inmates; similarly Mrs. Shaw, of the Chelsea School of Discipline which housed female juveniles, stated that, 'We allow no corporal punishment whatever'. Instead they used a combination of limited solitary confinement and withdrawal of privileges ${ }^{61}$. According to $0^{\prime} H a r a$ solitary confinement was more effective than corporal punishment, fitting in well with the prevailing penal ideologies of the mother country. In a journal entry for February $20^{\text {th }} 1838$, O'Hara Booth, remarked:

'Sick at heart from the number of boys obliged to punish - would that we had persons to work the system - with firmness but temper and patience to witness the results of perseverance - find myself breaking constitutionally rapidly - this is a trying situation - both for temper \& situation - but great good may be effected by firmness tempered with kindness and unremitting perseverance'62.

So how did the system of discipline set out by O'Hara Booth work in practice? A number of the boys had repeated instances of insubordination and punishment recorded on their conduct registers. For example, Samuel Holmes was in trouble approximately four times a year, between arriving in Van Diemen's Land in August 1836 and 1839. In November 1836 he was placed in the Black Hole for 13 days after being suspected of pilfering buttons from Government clothing. In December he was kept on bread and water for three days after using blasphemous language on the Sabbath. In January 1837, he received 15 lashes on the breech after a case of 'gross insolence to the 
Superintendent' ${ }^{63}$. In April of that year after misconduct on the muster ground he was put in solitary confinement with bread and water for three days. In July he was given twelve lashes for singing in his cell and improper conduct. In August he again received twelve stripes on the breech, as a result of determined opposition to his overseer... between his arrival in August 1836 and August 1838, Holmes received 104 lashes on the breech, approximately one for each week of that two years, he also received numerous punishments of solitary confinement, placement in the Black Hole, and a restricted $\operatorname{diet}^{64}$.

Holmes was not an anomaly. Thomas O'Donnell was aged fifteen on his arrival at the colony. Between his arrival in May 1836 and March 1838 he was whipped on the breech over a hundred times and spent approximately 53 days in solitary confinement. His 'offences' included, talking, fighting, throwing bread around the barracks, communicating with other boys in confinement, blasphemous language, and the usual improper conduct ${ }^{65}$. Age does not seem to have been much of a saving grace. James Gavagan was aged between eleven and twelve when convicted of stealing 21 umbrellas from a Finsbury doorway ${ }^{66}$. By the time he had arrived in Van Diemen's Land he was still only thirteen and the same petty disorder and punitive regime found in Holmes' and O'Donnell's registers is repeated in Gavagan's ${ }^{67}$. On May $22^{\text {nd }} 1837$, within three months of his arrival, he received twelve lashes on the breech after having absented himself for several hours ${ }^{68}$. A similar catalogue of what was clearly deemed anti-social behaviour in Point Puer, can be traced time and again through these registers. Thus a litany of offences can be found in the records of boys such as Charles Downes, James Jones, and Henry Underwood: pilfering bread from the ration (three days solitary confinement on bread and water), improper language to the teachers in school (48 hours solitary confinement), wilfully losing his cap and misconduct in school (48 hours solitary confinement on bread and water) ${ }^{69}$. Ultimately one is left with a sense not only of disobedience, but also of adolescent unruliness, all the more exaggerated, confined as these boys were within the bounds of the institution. Clearly, at least some boys devised a certain anti-authoritarian demeanour as a strategy for survival. Whilst this was not necessarily a conscious strategy, repudiating the system was one strategy the boys could opt for. Singing in your cell, shouting during divine service, destroying government property such as blankets, swearing at the overseer, absence from the establishment without authority, and refusing to perform work, suggest that boys should not be seen purely as helpless victims of the system.

However, these were also the actions of inmates directed not only at authority but also at each other. MacFie and Hargreaves have pointed to 'Point Puer's sub-culture which saw the weak preyed upon by the bully'70. Certainly incidences can be found to support this. For example in August 1837 Charles Downes received twelve stripes on the breech, for 'using a fellow boy'71. Similarly Thomas O'Donnell was disciplined several times in 1836 and 1837 for fighting during Government labour, for maltreating another boy, throwing stones at a fellow boy, and kicking a fellow boy at muster ${ }^{72}$. Perhaps the best evidence for such penal subcultures comes from the Euryalus hulk. Thus in 1835, an adult prisoner who worked in the juvenile convict hospital at Chatham, gave evidence to the Select Committee on Gaols regarding the boys he had encountered from the Euryalus. According to Dexter the Euryalus was dominated by internal hierarchies amongst the boy inmates:

'... there are what they call nobs, perhaps little boys that were not higher than the

table. I have seen them myself take a broomstick and strike a boy over the arm, 
almost to break his arm, and the other dare not say a single word to him... The nobs have got such an ascendancy, and they were so liked by the majority of the boys, that anybody that dared to say a word against them was sure to be pitched upon by all hands; and I have known it when three or four have been obliged to be locked up in a cell by themselves, in order to shelter them from murder, - that they would call Noseys, that is, those whom they considered had been to the officers to tell them any thing that was going on; those were particularly pointed out by the majority of prisoners on whom to wreak their vengeance ${ }^{73}$. According to nine-year-old Nicholas White, the bullied boys, particularly those who told, were known as 'skunks', who were liable to be beaten by the 'nobs'75. Such subcultures were perhaps an inevitable outcome of penal lives. That such bullying and intimidation carried on to Point Puer is then hardly surprising. In general terms the conduct of those of the Euryalus boys who went to Point Puer indicate that the system of reform was not working. Thus, few seem to have escaped the apparatus of reform that imposed such punitive and stringent regulations, and which produced the records of insubordination with which we are left. Moreover, the conflict that seemed to characterise the Point Puer experience may well have been a result of poor design. The establishment of Point Puer had in part been a response to the lack of provision for the young and unskilled. Arguably, it failed in its attempt to address the lacunae that existed between the needs of the colony and the lack of credentials of the majority of juvenile offenders.

The nineteen boys interviewed by Miles were probably typical of the juvenile offenders who arrived in Van Diemen's Land, to be assigned to masters or sent to Point Puer. Thus these were urban youths, most of whom had experienced some employment; however, under-employment was common, and the work they undertook was overwhelmingly unskilled ${ }^{76}$. The deciding factor directing a boy to Point Puer seems to have been his age - all but one of the eight boys who went there were aged under sixteen $^{77}$. One explanation for this was that younger boys were less likely to be skilled. However, all but one of the boys interviewed by Miles were described either by the generic category of 'labourer' or as 'boy'78. Such boys were not very employable in the context of the colonial establishment. MacFie and Hargreaves point out that the most sought after convicts were those with experience of domestic service, agricultural and mechanic work ${ }^{79}$. Clearly many juvenile offenders did not necessarily fit into these categories. As Hamish Maxwell-Stewart has argued, 'private employers were reluctant to pay juveniles at the standard convict rate and receive in return only a small proportion of the output they could expect from adults. On the other hand, public sector allocation was highly skill specific. Beyond a few openings for errand boys, the public works had little use for child labour' ${ }^{\prime 80}$. Thus police magistrate Matthew Forster complained that juveniles were 'a dead weight upon the government'. MacFie and Hargreaves suggest that Point Puer was a receptacle for those unskilled boys who could not be assigned ${ }^{81}$. Nevertheless, as we have seen, other than age, there is no easy distinction to be made between the group of boys who were assigned and those who went to Point Puer. Only in four cases was there firm information about how the assigned boys were appropriated, in the form of a master's name. Thus Michael Driscoll (who was assigned then later sent to Point Puer to learn a trade), John Murphy, George Hickman and Peter Conley were all assigned to masters, though there is no detail as to the nature of the work ${ }^{82}$. 
While those boys who were assigned to masters upon their arrival in Van Diemen's Land were not subjected to the same level of carceral gaze as their fellow convicts at Point Puer, it is clear that their status as convicts shaped the boundaries of the master/ servant relationship. Indeed Arthur's system of surveillance, reinforced by the 1830s with a force of convict mounted police, was such that a good account of the conduct of convicts was kept 'from their day of their landing until... their emancipation or death's3. The system was further bureaucratised by the creation of the Black Books, which recorded the errant convict's activities ${ }^{84}$. Certainly the notion of reform envisaged by Arthur was one that took place within a very circumscribed world. For some of the boys from the Euryalus it is clear that the boundaries of that world were there to be tested. Not surprisingly, unlike the boys who went to Point Puer, where the levels of misconduct were fairly consistent, those boys who were assigned to masters, or to a government department had more varied experiences. This may be indicative of the particular master/servant relationship. However, this variation of experience might also be explained by looking at the boys' backgrounds and conduct registers. There is a sense that boys perceived of as 'hardened' or 'bad' in their past behaviour continued to be shaped by that label. Thus the boys who had claimed to be most au fait with London's criminal subculture were often the boys with the poorest records of conduct. For example, William Cook had been flogged and cross-ironed on the transport, Asia, his conduct being so bad. From his arrival in February 1836 Cook veered between hard labour, lashes and solitary confinement for neglecting his duty, disobeying orders, and generally being in the wrong places at the wrong times ${ }^{85}$. In 1838 , after being sent out to work, after stealing some bread from his master his sentence was extended for a year, and he was returned to the Government, hence back to the penal institution. After this he was loaned out to various chain gangs, where again he was charged with wilful misconduct and mismanagement of his work. He finally received his free certificate in 1843, after seven years of O'Hara Booth's strict regime.

30 A similar catalogue of insubordination and punishment by hard labour, and stints in the labouring gangs can be found in the record of sixteen-year-old George Hickman, whom we met earlier, and who apparently told Miles, 'I never have worked since I began thieving ${ }^{86}$. This association, between what were seen as 'hardened' juveniles and poor conduct can only ever be impressionistic. However, many of the boys experienced the rigours of gang labour. As MacFie and Hargreaves have illustrated, the chain-gang was often used indirectly or more directly as a punishment, "placement in a chain gang was aimed particularly at boys who were insubordinate or who absconded ${ }^{87}$. Research by Maxwell-Stuart further supports this. He argues that young, unskilled workers quickly became trapped in a system which rewarded the skilled, and was not favourably disposed to bearing the costs of training the young. Gang labour was often the destination for recidivist, urban, juvenile offenders, 'twenty-, thirty- and fortysomething blacksmiths, clerks and ploughmen were, on the whole, well treated while teenage weavers and labourers were disproportionately exposed to the rigours of gang management' ${ }^{\prime 8}$. Out of the nineteen boys from the Euryalus, ten definitely experienced gang labour, suggesting that a combination of youth, poor conduct, and lack of experience and skills made these boys more vulnerable to punishment, either through the chain-gang, or by a combination of the birch and solitary confinement ${ }^{89}$. It seems then that whilst boys like Cook and Hickman may have escaped Point Puer because of their age, their lack of skills and potential as convict workers, combined with their identities as 'hardened' juveniles, meant that they were subject to very similar 
experiences of discipline as their fellow Point Puer boys. Ultimately Cook and Hickman survived their years at Van Diemen's Land, others were not so fortunate. Michael Driscoll, who had considered his course of crime terminated for seven years, was terminated permanently. Just over a year after his arrival, after having been found with tobacco in his possession he was sent to spend three weeks on no. 3 chain gang, but less than a month after this, at the age of eighteen, he was dead ${ }^{90}$.

\section{Conclusion}

In the 1830s the concept of reformation was carried to the Australian colonies as part of the new penal language. As we have seen O'Hara Booth was well-versed in the semantics of British and Western European penality. In Britain though, reformation was shaped by the impact of philanthropy, a very visible and potent adjunct to an increasingly interventionist state. Whilst problems continued in British gaols and the new penitentiaries, the involvement of individual philantropists in the penal system perhaps kept a check on some of the worst abuses. In Van Diemen's Land, in contrast, despite the unblinking carceral gaze, the language of reformation remained an ideal rather than a reality. The system instituted at Point Puer was concerned with containment rather than reform. Whilst the rhetoric of reform had its uses, the truth was that boys went to Point Puer because there was nowhere else for them to go. Notions of reformation may well have been used in the attempt to make boys into more useful workers, however, as we have seen, control and discipline fundamentally structured the regime at Point Puer. Moreover, older assigned youths who lacked the necessary skills in order to 'get on' in the colony, were similarly subject to harsh, disciplinary regimes - particularly the chain gang.

Yet it would be a mistake to see reformation only as rhetoric. Throughout the criminal justice system prevalent ideologies implicitly affected the choice of whom went to Australia. Criminal justice systems are always systems of negotiation, where ideological and legislative developments constantly interact as a response to contemporary criminological rhetoric. Arguably by the mid-nineteenth century we can see the crossfertilisation of ideas which, I suggested earlier, were a hallmark of the developing juvenile justice system. As well as ideas from the reformatory systems of continental Europe, the Australian experience was implicit in the systems that developed from the 1840s. Thus, increasingly, suitable juveniles followed what we might call a penal pathway from imprisonment to re-education to compulsory emigration. Children who were suitable for reformation were to be remodelled into colonial citizens, receiving the training via institutional provision at home, rather than sending untrained and unskilled boys abroad. Parkhurst, established by act in 1838 , exemplified this model ${ }^{91}$. Leon Radzinowicz points out: 'Parkhurst rapidly developed into a kind of 'industrial school', preparing boys for colonial life' ${ }^{\prime 2}$. A number of other schemes, both voluntary and state-run, were also based on the premise of agricultural training and other 'useful' skills $^{93}$. Thus in 1851 Captain William. J. Williams, the state Inspector of Prisons, visited boys in the Metropolitan Houses of Correction to handpick those boys whom he deemed 'fitting objects' for the Philanthropic Societies Farm School and then for colonial emigration. Commenting on a fifteen-year-old at Tothill Fields, Williams wrote, 'The evident cause of this boy's lapse from honesty is the drunkenness and neglect of his father; he can read and write; seems desirous of leading a better life; is well spoken 
of by the prison officers; has no objection to go abroad, and I think is a very good subject for admission to the Philanthropic ${ }^{994}$.

Point Puer was disbanded in 1847, by 1853 the order-in-council making Van Diemen's Land a penal colony was revoked ${ }^{95}$. However, juveniles continued to be transported to Western Australia - most of these came from Parkhurst. Western Australia lacked economic stability, and as a result the settlers welcomed convict labour. Thus for a few years this became the destination for newly reformed juvenile offenders, carrying the reformatory ethos abroad. Transportation was no longer to be dreaded as a punishment, but rather was repackaged as an aspiration - by placing children in families, using their training as agricultural labourers and domestic servants, reformation could be accomplished rather than fade under the auspices of a brutal penal regime ${ }^{96}$. In 1853 , the sentence of transportation for less than fourteen years was abolished, which effectively meant the end of state juvenile transportation, although poor and delinquent children continued to be sent to Australia and to Canada under the auspices of the voluntary emigration schemes of the later nineteenth century.

This article has considered the development of juvenile specific reformatory ideals during the transportation period. The emigration of children, whether in its state or voluntary form, was strongly influenced by prevailing attitudes both to crime and juvenile delinquency. That these attitudes sometimes clashed with the ideals of reformation is not surprising. However, as this article has shown, elite ideals and reformatory strategies had very real implications for the juvenile penal subject. Despite a rhetoric that portrayed the juvenile offender as a suitable colonial subject, slipping such children into the penal terrain of Van Diemen's Land was not straightforward. Consequently, juveniles with few or no useful skills were superfluous to the economic agendas of the colony. Young delinquents may have been 'objects of compassion', but the system that awaited them at Port Arthur and Point Puer was not the solution ${ }^{97}$.

\section{BIBLIOGRAPHY}

Arnot, M. L., Usborne, C., Gender and Crime in Modern Europe, London, UCL Press, 1999.

Bean, P., Melville, J., Lost Children of the Empire, London, Unwin Hyman, 1989.

Blackburn, G., The Children's Friend Society: Juvenile Emigrants to Western Australia, South Africa and Canada, 1834-1842, Northbridge, WA, 1994.

Bradlow, E., The children's friend society at the Cape of Good Hope, Victorian Studies, 1984, 27, pp. 155-177.

Budee, P., The Fate of the Artful Dodger, Perth, 1984.

Campbell, C., The Intolerable Hulks: British Shipboard Confinement, 1776-1857, London, Heritage Books, 1993.

Carlebach, J., Caring for Children in Trouble, London, Routledge and Kegan Paul, 1970. 
Carpenter, M., Reformatory Schools for the Children of the Perishing and Dangerous Classes and for Juvenile Offenders, London, C. Gilpin, 1851, repr. 1968.

Colquhoun, P., A Treatise on the Police of the Metropolis: Explaining the Various Crimes and Misdemeanours which at Present are Felt as a Pressure upon the Community: and Suggesting Remedies for their Prevention, London, C. Dilly, 1796.

Cox, P., Shore, H., (Eds), Becoming Delinquent: European Youth, 1560-1960, Aldershot, Ashgate, 2002.

Damousi, J., Depraved and Disorderly: Female Convicts, Sexuality and Gender in Colonial Australia, Cambridge, Cambridge University Press, 1997.

Driver, F., Discipline without frontiers? Representations of the mettray reformatory colony in Britain, 1840-1880', Journal of Historical Sociology [Great Britain], 1990, 3, pp. 272-293.

Evans, R., Thorpe, W., Power, punishment and penal Labour: convict workers and Moreton Bay, Australian Historical Studies, 1992, 25, 98, pp. 90-111.

Fielding, J., Fielding, H., An Account of the Origin and Effects of a Police set on foot by his Grace the Duke of Newcastle in the year 1753, upon a plan presented to his grace by the late Henry Fielding, esq. To which is added a plan for Preserving those Deserted Girls in this Town, who become Prostitutes from Necessity, London, 1758.

Hadley, E., Natives in a strange land: the Philanthropic discourse of juvenile emigration in midnineteenth century England, Victorian Studies, 1990, 33, pp. 411-437.

Hanway, J., The Defects of the Police, the Cause of Immorality and the Continual Robberies Committed, Particularly in and about the Metropolis, London, 1775.

Heard, D., (Ed.), The Journal of Charles O'Hara Booth: Commandant of the Port Arthur Penal Settlement, Tasmania, Tasmanian Historical Research Association, 1981.

Hetherington, P., Child labour in Swan River Colony, 1829-1850, Australian Historical Studies, 1992, 25,98, pp. 34-52.

Highmore, A., Philanthropia Metropolitana, London, 1822, pp. 519-574.

Hooper, F. C., The Point Puer Experiment: A Study in Penal and Educational Treatment of Juvenile Transportees in Van Diemen's Land, 1830-1850, Med thesis, Univ. of Melbourne, 1954.

Hooper, F. C., Prison Boys of Port Arthur, Melbourne, F. W. Cheshire, 1967.

Hughes, R., The Fatal Shore: A History of the Transportation of Convicts to Australia, 1787-1868, London, Collins Harvill, 1987.

Humphrey, K., Objects of compassion: young male convicts in Van Diemen's Land, 1834-1850, Australian Historical Studies, 1992, 25, 98, pp. 13-33.

Johnson, W. B., The English Prison Hulks, London, Christopher Johnson, 1957.

King, P., The rise of juvenile delinquency in England, 1780-1840: changing patterns of perception and prosecution, Past and Present, 1998, 160, August, pp. 116-166.

Kyle, A., Comment - Little depraved felons, Australian Historical Studies, 1992, 25, 99, pp. 319-324.

Lempriere, T., The Penal Settlements of Van Diemen's Land, 1839, Royal Society of Tasmania, Northern Branch, Hobart, 1954.

Leonards, C., Border crossings: Care and the 'criminal child' in nineteenth century european penal congresses in Cox, P., Shore, H. (Eds), 2002, Becoming Delinquent: European Youth, 1560-1960, Aldershot, Ashgate, pp. 105-121. 
MacFie, P., Hargreaves, N., The empire's first stolen generation: the first intake at Point Puer, 1834-1839, Exiles of Empire: Tasmanian Historical Studies, 1999, 6, 2, pp. 129-154.

Magarey, S., The invention of juvenile delinquency in early nineteenth-century England, Labour History [Canberra], 1978, pp. 11-27.

Mahood, L., Policing Gender, Class and Family: Britain, 1850-1940, London, UCL Press, 1995.

Maxwell-Stewart, H., The Bushrangers and the Convict System of Van Diemen's Land, 1803-1846, Ph.D, Edinburgh, 1990.

Maxwell Stewart, H., Convict workers, 'Penal Labour' and Sarah Island: Life at Macquarie Harbour, 1822-1834, in Duffield, I., Bradley, J., (Eds), Representing Convicts: New Perspectives on Convict Forced Labour Migration, Leicester, Leicester University Press, 1997, pp. 142-162.

May, M., Innocence and experience: The evolution of the concept of juvenile delinquency in the mid-nineteenth century, Victorian Studies, 1973, Sept., pp. 7-29.

McConville, S., A History of English Prison Administration, vol. I, 1750-1877, London, Routledge and Kegan Paul, 1981.

Miles, W. A., Poverty, Mendicity and Crime, London, Shaw and Sons, 1839.

Nicholas, S., (Ed.), Convict Workers: Reinterpreting Australia's Past, Cambridge, Cambridge University Press, 1988.

Philips, D., Storch, R., Policing Provincial England, 1829-1856: The Politics of Reform, Leicester, Leicester University Press, 1999.

Philips, D., The royal bastard as policeman? William Augustus Miles and the Sydney police, 1841-1848, in Philips, D., Davies, S., (Eds), A Nation of Rogues? Crime, Law and Punishment in Colonial Australia, Melbourne, Melbourne University Press, 1994, pp. 36-72.

Pinchbeck, I., Hewitt, M., Children in English Society, vol. 2: from the Eighteenth Century to the Children's Act 1948, London, Routledge and Kegan Paul, 1973.

Platt, A., The Child Savers: the Invention of Delinquency, Chicago, Chicago University Press, 1969.

Radzinowicz, L., Hood, R., A History of English Criminal Law and its Administration from 1750, V: the Emergence of Penal Policy, Oxford, Stevens and Sons, 1986, Oxford University Press edition, 1990.

Rush, P., The government of a generation: The subject of juvenile delinquency, Liverpool Law Review, 1992, 14, pp. 3-43.

Shaw, A. G. L., Convicts and the Colonies: A Study of Penal Transportation from Great Britain and Ireland to Australia and other parts of the British Empire, London, Faber, 1966.

Shore, H., The Social History of Juvenile Crime in Middlesex, 1790-1850, Ph.D, London, 1996.

Shore, H., Artful Dodgers: Youth and Crime in Early Nineteenth-Century London, Woodbridge (Suffolk), Boydell Press, 1999a.

Shore, H., The trouble with boys: Gender and the 'invention' of the juvenile offender in early nineteenth-century Britain, in Arnot, M. L., Usborne, C., Gender and Crime in Modern Europe, London, UCL Press, 1999b, pp. 75-92.

Wonter, T., Old Bailey Experience: Criminal jurisprudence and the Actual Working of our Penal Code of Laws... London, James Fraser, 1831. 


\section{NOTES}

1. I would like to thank the following: Nigel Hargreaves for his generosity and advice on the Point Puer boys; Peter King for reading and commenting on an earlier version of this article; Hamish Maxwell-Stewart for both reading the article and suggesting some fruitful lines of enquiry.

2. Select Committee Report (hereafter SC), PP (1818), VIII, p. 171, evidence of Rev. H. S. Cotton, Ordinary of Newgate.

3. William's response may have been shaped by the directions of his interviewers, or more probably by the fact that he was the victim of severe bullying by other boys on the Euryalus (the juvenile convict hulk, moored at Chatham). Public Record Office (hereafter PRO): HO73/16, loose papers, rough notebooks, vol. iv.

4. Hooper (1954, 1967); Budee (1984); Humphery (1992).

5. MacFie, Hargreaves (1999); Kyle (1992).

6. For juvenile offenders during the period of transportation see King (1998); Magarey (1978); May (1973); Radzinowicz, Hood (1990) esp. part. 3; Rush (1992); Shore (1999).

7. Humphrey (1992).

8. For a reliable account of penal developments in this period see McConville (1981), see particularly chapters 5-7.

9. This was a distinction made familiar by Mary Carpenter (1851).

10. This process was finalised in 1876 under the Education Act, which established day industrial schools and truant schools. Reformatory Schools Act, 17 \& 18 Vict. c. 74; Reformation of Young Offenders Act (17 \& 18 Vict. c. 86), Middlesex Industrial Schools Act [Local] (17 \& 18 Vict. c. 169); 1855, Youthful Offenders Amendment Act (18 \& 19 Vict. c. 87); Elementary Education Act, 39 \& 40 Vict. c. 79 (1876). Separate institutional provision complemented the earlier Juvenile Offenders Act of 1847 which had confirmed the principle of summary trial for children up to the age of 14 , this was extended to 16 in 1850. Juvenile Offenders Act, 10 \& 11 Vict. c. 82 (1847); 'An Act for the further Extension of Summary Jurisdiction in Cases of Larceny', 13 \& 14 Vict. c. 37 (1850).

11. For the general background to child emigration schemes see Bean, Melville (1989). For more specific discussion of the nineteenth century emigration schemes see Blackburn (1994); Bradlow (1984); Hadley (1990).

12. See Carlebach (1970, pp. 25-46); McConville (1981, pp. 204-210); Radzinowicz, Hood (1990, pp. 148-155).

13. Transportation Act, 4 Geo. I, c. II (1718). Even prior to this, from 1618, the Virginia Company had petitioned the Burghers of the City of London for their unwanted children. Duly a hundred such children were shipped acros the Atlantic. This practice apparently continued sporadically throughout the century. Bean, Melville (1989, p. 29).

14. Hooper (1954). Cited in Humphery (1992, p. 17). See also Shore (1996, pp. 180-183).

15. Clearly the terms juvenile and young offender were often used somewhat fluidly. In my own work I have used the definition of sixteen and under for juvenile, however, this is a limiting definition. For example, many of the boys transported were juvenile when originally sentenced, but over sixteen by the time of transportation. Suffice it to say the age-range of the boys of whom I am talking is between 13-18. Moreover, impressionistically at least, most juvenile offenders sentenced to transportation, seem to have had their sentenced carried through. Certainly, even the most cursory glance across the petition archive held at the Public Record Office at Kew, shows little evidence of successful petitioning. PRO: HO17/18, petition archives 1819-39, 1839-54; HO19, petition archive register.

16. In my own work, sampled from the Middlesex Criminal Registers, $84.6 \%$ of those transported were done so for larceny of one sort or another (this could range from petty larceny to the more serious larceny from the dwelling house). In the case of juvenile offenders larceny accounted for $94 \%$ of the crimes of those transported, Shore (1999, pp. 133, 169). 
17. Old Bailey Sessions Papers (hereafter OBSP): Mary Tyler, 7th session, 1809, no. 634, pp. 403-404.

18. PRO: HO73/16, notebook no. 1, testimony of Robinson.

19. Campbell (1993, p. 129).

20. The Bellerophon was reserved for juveniles from mid-1824 until the end of 1825 when they were transferred to the Euryalus hulk, said to be 'specially fitted for them'. In reality the hulk was beset by problems and attendant controversy for much of the decade or so that it was in use. For instance, in 1831 Thomas Wontner launched a blistering attack on the Euryalus in his book, old Bailey Experience, prosaically pointing out that, 'If there be any regular and established schools for teaching crime, the ship Euryalus is the place', Wonter (1831, pp. 360-361). For information on the Bellerophon and Euryalus see Johnson (1957); Campbell (1993, pp. 129-140); Radzinowicz, Hood (1990, pp. 142-148).

21. SC, PP (1835), 4 \& 5, XII, p. 508, evidence of Mr. William Augustus Miles.

22. See Nicholas (1988) for discussions of the economic agenda fuelling transportation. For a more recent critique see Evans, Thorpe (1992, pp. 90-111).

23. Report of the Committee for Investigating the Causes of the Alarming Increase of Juvenile Delinquency in the Metropolis (Dove, London, 1816). See Highmore (1822, pp. 519-574).

24. Shore (1996, p. 60, n. 23).

25. For example, Hanway (1775), Fielding (1758), Colquhoun (1796) were all active in the reform debate in the eighteenth century.

26. See Carlebach (1970); Pinchbeck, Hewitt (1973). For similar movements in America see Platt (1969).

27. This 'relationship' however, was not to reach its peak until the mid-century, when institutions aimed at both delinquent and 'at risk' children predominated, Mahood (1995).

28. Leonards (2002).

29. SC Gaols and Houses of Correction, $1^{\text {st }}$ Report, PP (1835), XI, p. 4, evidence of William Crawford, esq.

30. 'Report on the System and Arrangements of «La Colonie Agricole» at Mettray: presented to the Committee of the Philanthropic Society, St. George's Fields, 19 August 1846'. Papers delivered by the Rev. Sydney Turner, see App. 8 in SC Criminal and Destitute Juveniles, PP (1852), VII, pp. 484-493. Captain Maconochie published an account of Mettray in The Athenaeum, in 1846, A. Maconochie, 'Mettray', The Athenaeum, March 21, 1846. See also Driver (1990).

31. For example see Report of the proceedings of a conference on the subject of preventative and reformatory schools, held at Birmingham, on the $9^{\text {th }}$ and $10^{\text {th }}$ December (London, 1851), repr. in SC Criminal and Destitute Juveniles, PP (1852), VII, app. 6, p. 443. International penitentiary congresses were held from 1846, the first in Frankfurt. See Leonards (2002).

32. Carpenter (1851, pp. 321-322). For Carpenter's attacks on Parkhurst see Radzinowicz, Hood (1990, p. 169).

33. The juvenile prison hulk moored at Chatham, on the River Medway, in the 1830s. PRO: H073/16, notebooks 1, 2, 3. For a detailed discussion of this source and for details of the boys experiences on the Euryalus, see Shore (1999, pp. 107-108, 125-126, 129-131, 155-157).

34. The interviews seem to have been conducted as part of the investigations into the constabulary in the late 1830s. Miles was a shadowy figure in British and Australian History. Miles had been close to Edwin Chadwick the main architect of the Constabulary Commission and during the 1830s developed an interest in poverty and crime, resulting in a book, Poverty, Mendicity and Crime (1839). David Philips has written extensively about Miles activities, both in Britain and Australia. D. Philips, 'An Uneasy Moral Entrepreneur in England and Australia: William Augustus Miles on Police, Pauperism and Crime in the 1830s and 40s' (Paper delivered at the Fifth Australian Modern British History Association Conference, University of Melbourne, 
November, 1987); and Philips (1994). Miles' particular role in the Constabulary Commission is discussed in Philips, Storch (1999, pp. 116, 118-119).

35. Not all juvenile offenders were automatically sent to Point Puer. Of the nineteen boys that I am concerned with, all of whom were held on the juvenile hulk at Chatham, only eight spent time at Point Puer, the others were assigned to masters in various parts of Van Diemen's Land upon their arrival. For this and other information on Point Puer, I am indebted to Nigel Hargreaves. See MacFie, Hargreaves (1999). The nineteen boys are: Frederick Arnold, no. 706, aged 18, assigned; Rowland Bassett, no. 2433, aged 16, assigned; Peter Conley, no. 2014, aged 16, assigned; William Cook, no. 1986, aged 16, assigned; John Darville, no. 1091, aged 16, assigned; Thomas O'Donnell, no. 1106, aged 15, Point Puer; Charles Downes, no. 1105, aged 15, Point Puer; Michael Driscoll, no. 1088, aged 15, assigned/Point Puer; James Edwards, no. 489, aged 15, assigned; James Gavagan, no. 1148, aged 13, Point Puer; George Hickman, no. 2059, aged 16, assigned; Samuel Holmes, no. 2078, aged 14, Point Puer; James Jones, no. 1044, aged 14, Point Puer; Philip Maine, no. 1426, aged 15, assigned; John Murphy, no. 1406, aged 16, assigned; George Reid, no. 1145, aged 16, assigned; Henry Underwood, no. 31, aged 16, Point Puer; George Webster, no. 2341, aged 15, Point Puer; Thomas White, no. 2071, aged 16, assigned.

36. A second set of interviews of juvenile offenders includes boys from Glasgow, Paisley, Manchester, Exeter, Nottingham and Wolverhampton. PRO: HO73/16, rough notebooks, iii, iv, v. 37. PRO, HO73/16, notebooks 1, 2, 3; HO73/16, rough notebooks iii, iv, v. See appendix 1 in Shore (1999, pp. 155-157) for a full description of these notebooks.

38. PRO: HO73/16, notebooks no. 1-3.

39. Archives Office of Tasmania (hereafter AOT): CON 31/21, 31/11, 31/21.

40. For a discussion of the conflict between masculinity/maturity and childishness/immaturity see Shore in Arnot, Usborne (1999, pp. 75-92).

41. PRO: HO73/16, notebook no. 1.

42. PRO: HO73/16, notebooks no. 3.

43. PRO: HO73/16, notebook no. 3.

44. Ibid.

45. PRO: HO73/16, notebook no. 2.

46. Hughes (1987, p. 400).

47. Lempriere (1954, p. 61).

48. 'Puer' being from the latin for boy.

49. Radzinowicz, Hood (1990, pp. 140-141).

50. Humphrey (1992, pp. 19-25).

51. See Maxwell Stewart (1997, pp. 142-162). See p. 148 for comment on retraining.

52. See Blackburn (1994); Bradlow (1984); Hadley (1990).

53. SC Gaols and Houses of Correction, PP (1835), XI-XII, p. 508, evidence of W. A. Miles.

54. Charles O'Hara Booth, 'Report on the Juvenile Establishment at Point Puer', 24 July 1837. Cited in Bruce Rosen, 'Victorian Childhoods and the Point Puer Boys', p. 3, Point Puer Web Site (http:// freehosting1.at... tpuer-webjump/child.htm).

55. SC Gaols and Houses of Correction, PP (1835), XI-XII, p. 509.

56. Heard (1981).

57. Hughes (1987, p. 412).

58. Heard (1981, pp. 50-51).

59. SC Transportation, PP (1838), XXII, app. B, no. 38, p. 220.

60. Ibid.

61. SC Gaols and Houses of Correction, PP (1835), XI-XII, p. 100, evidence of Mr. Charles Forss; p. 398, evidence of Mrs. Shaw.

62. Heard (1981, p. 222). 
63. Point Puer was hardly unusual in its use of corporal punishment for boys. Joy Damousi has pointed to the violent physical behaviour that characterised the punishment of boys in the male orphan schools established for the children of convicts and poor children, Damousi (1997, pp. 136-137).

64. AOT: CON31/21.

65. AOT: $C O N 31 / 11$.

66. OBSP, 5 th session, 1835 , no. 853 , p.846.

67. PRO: CRIM 4/5 no. 201; AOT: CON31/16.

68. AOT: CON31/16.

69. AOT: $\operatorname{CON} 31 / 11,31 / 25,31 / 44$.

70. MacFie, Hargreaves (1999, p. 144).

71. AOT: CON 31/11, no. 1105.

72. AOT: CON 31/11, no. 1106.

73. SC Gaols and Houses of Correction, PP (1835), XI-XII, Ist report, p. 323.

74. PRO: HO 73/16, rough notebook iv, evidence of Harris in the name of Johnson. See Shore (1999, pp. 130-131) for a fuller description of this case.

75. PRO: HO 73/16, rough notebook v, evidence of Nicholas White.

76. Shore (1999, pp. 39-43).

77. See AOT/CON 18, Description Lists of Male Convicts, 1828-53. These lists contain details of the physical appearance of convicts.

78. Michael Driscoll, who died in May 1837 aged eighteen, was described as a 'house lad'. AOT: CON31/11.

79. MacFie, Hargreaves (1999, p. 130).

80. Maxwell-Stewart (1990, pp. 149-150).

81. MacFie, Hargreaves (1999, p. 130).

82. AOT: CON27/2, appropriation lists of convicts, 2 vols; for Driscoll, CS01/851/17986, appropriation lists that date from 1823-1839.

83. Shaw (1966, pp. 199-200).

84. The material from AOT/CON 31/passim that I have used in this article. These books, compiled by a transported law stationer Edward Cook under the Superintendence of the Muster Master, Joseph Spode, gave the convict's history before arrival and the details of his career in the colony.

85. AOT: $\operatorname{CON} 31 / 7$.

86. PRO: HO73/16, notebook no. 1.

87. Ganged labourers accounted for $58 \%$ of all deaths recorded at the settlement in the period 1832-1843. MacFie, Hargreaves (1999, pp. 133, 144).

88. Maxwell-Stuart (1997, pp. 146-147).

89. MacFie and Hargreaves point out that boys at Point Puer were initially sent to work in labouring gangs (1999, p. 133).

90. AOT: $\operatorname{CON} 31 / 11$.

91. 'An Act for establishing a Prison for Young Offenders', 1 \& 2 Vict. c. 82 (1838), ss. 3 \& 4. Though from its inception Parkhurst was subject to criticism, particularly from Mary Carpenter. See Radzinowicz, Hood (1990, pp. 148-155).

92. Ibid., p. 154.

93. The most well-known and controversial of these being the Children's Friend Society, established in the 1830s by Captain Edward Pelham Brenton, a farm-school in rural Hackney Wick was set up with the aim of training children for colonial emigration. See Blackburn (1994).

94. SC Criminal and Destitute Juveniles, PP (1852), VII, app. 1, p. 400.

95. Shaw (1966, p. 351). 
96. In practise, of course, this desired end was not always achieved as the experience of the children sent to the Swan River Colony, and the later experience of children sent to various outposts of the empire, attests. See Hetherington (1992).

97. This phrase comes from Charles O’Hara Booth. Heard (1981, p. 27).

\section{ABSTRACTS}

Many juvenile offenders transported from Britain to Van Diemen's Land in the 1830s spent time in the juvenile specific penal station, Point Puer. Here they were subjected to a reform ideology, also transported from the Mother Country, which provided the training and discipline to make them into new colonial subjects. However, this reformatory programme was marred by the more pragmatic needs of an economically deterministic colony. One in which fifteen and sixteen-yearold youths from British cities and urban conurbation's, with few skills and uneven experience of work, had no place. This article follows a specific group of boys transported to Van Diemen's Land in the mid-1830s, some of whom were sent to Point Puer, and the others assigned to masters, considering their experiences at the colony in the context of both reform and the broader disciplinary regime.

De nombreux délinquants juvéniles transportés de Grande-Bretagne vers la région de Van Diemen (Australie) dans les années 1830, ont passé un certain temps dans une institution spécifique, Point Puer. Ils y étaient soumis à une idéologie réformatrice, également originaire de la mère-patrie, sur laquelle étaient fondées la formation et la discipline destinées à les transformer en sujets des colonies. Toutefois, ce programme était entravé par les exigences plus pragmatiques de l'économie de la colonie, où n'avaient pas leur place des jeunes de 15 à 16 ans originaires des zones urbaines britanniques, dotés de savoir-faire limités et d'une expérience du travail chaotique.

Cet article s'attache à un groupe particulier de garçons transportés dans cette région au milieu des années 1830, dont certains séjournèrent à Point Puer et d'autres furent confiés à des maîtres, et analyse leur expérience coloniale dans le contexte à la fois du régime d'amendement et du dispositif disciplinaire plus large.

\section{AUTHOR}

\section{HEATHER SHORE}

School of Social, Historical and Literary Studies, University of Portsmouth, Mildam, Burnaby Road, UK-Portsmouth, P01 3AS, heather.shore@port.ac.uk Heather Shore is currently lecturer in the School of Social, Historical and Literary Studies, University of Portsmouth. Her main publications include: Artful Dodgers: Youth and Crime in Early Nineteenth Century London (Boydell Press, 1999); with Pam Cox, Becoming Delinquent: British and European Youth, 1650-1950 (Ashgate, 2002), with T. Hitchcock, The Streets of London: From the Great Fire to the Building of the Embankment (Rivers Oram Press, forthcoming); 'Cross Coves, Buzzers and General Sorts of Prigs: Juvenile Crime and the Criminal 'Underworld' in the Early Nineteenth Century', British Journal of CriminologyonHistories of Crime and Modernity, vol. 39, no. 1, 1999, pp. 
10-24. She is currently writing a history of the idea of the underworld, to be published by London books as a monograph, Underworlds: Professional and Organised Crime in London Since 1700. 